\title{
Do We Need a (New) Theory of Lexicography?
}

\author{
Sven Tarp, Department of Afrikaans and Dutch, University of Stellenbosch, \\ South Africa and Centre for Lexicography, Aarhus University, Denmark \\ (st@asb.dk)
}

\begin{abstract}
In the current transition from printed to electronic dictionaries the question has been raised whether we need a new theory of lexicography that may guide the conception and production of lexicographical e-tools or if we can use the theories already developed in the era of printed works. In order to answer this question the article first of all discusses the question whether a lexicographical theory exists, is possible at all or even wanted. It shows that the various approaches to this question are mainly due to the fact that the very concept of theory is widely disputed within lexicographical circles. In this respect, it briefly discusses the Anglo-Saxon academic tradition according to which science is only related to natural phenomena and where all other phenomena are referred to the spheres of art and craft, and it shows that this tradition is widely opposed by the traditions in other parts of the world. Upon this basis, the article shows that a lexicographical theory is not only possible but that various highly useful theories already exist. Finally, it claims that these theories, especially the ones that are not only focusing on the printed dictionary form, should not be rejected but should be further enhanced and improved in close interaction between lexicography and other consultation disciplines within the broad area of information science.
\end{abstract}

Keywords: LEXICOGRAPHY, LEXICOGRAPHICAL THEORY, CONCEPT OF LEXICOGRAPHICAL THEORY, FUNCTION THEORY, ACADEMIC STATUS OF LEXICOGRAPHY, INTERDISCIPLINARY VOCATION OF LEXICOGRAPHY, DICTIONARIES, CONSULTATION TOOLS, INFORMATION SCIENCE

Opsomming: Bestaan daar 'n behoefte aan 'n (nuwe) leksikografieteorie? Tydens die huidige oorgang van gedrukte na elektroniese woordeboeke is die vraag geopper of ons 'n nuwe leksikografieteorie benodig wat die ontwerp en produksie van leksikografiese egereedskap kan rig en of ons die teorieë wat reeds ontwikkel is tydens die era van gedrukte werke kan gebruik. Om hierdie vraag te beantwoord bespreek die artikel eerstens die vraag of 'n leksikografieteorie bestaan en of dit enigsins moontlik of selfs wenslik is. Dit toon dat die verskillende benaderings tot hierdie kwessie hoofsaaklik te danke is aan die feit dat die hele konsep van teorie wyd binne leksikografiese kringe betwis word. Kortliks word die Angel-Saksiese akademiese tradisie bespreek waarvolgens die wetenskap slegs betrekking het op natuurlike verskynsels en waar alle ander verskynsels binne die sfeer van die kunste en vaardighede val. Dit toon ook dat hierdie tradisie in groot teenstelling is met die tradisies in ander dele van die wêreld. Vanuit hierdie vertrekpunt toon die artikel dat 'n leksikografieteorie nie alleen moontlik is nie, maar dat verskeie hoogs nuttige teorieë reeds bestaan. Ten slotte word beweer dat hierdie teorieë, veral dié wat nie net fokus op die gedrukte woordeboekvorm nie, nie verwerp behoort te word nie, maar verder uitgebrei en verbeter moet word in noue wisselwerking tussen die leksikografie en ander raadple- 
gingsvakrigtings binne die breë veld van die inligtingswetenskap.

Sleutelwoorde: LEKSIKOGRAFIE, LEKSIKOGRAFIETEORIE, KONSEP VAN LEKSIKOGRAFIETEORIE, FUNKSIETEORIE, AKADEMIESE STATUS VAN DIE LEKSIKOGRAFIE, INTERDISSIPLINÊRE LEKSIKOGRAFIEBEROEP, WOORDEBOEKE, RAADPLEGINGSHULPMIDDELS, INLIGTINGSWETENSKAP

\section{Introduction}

Lexicography is in the middle of a challenging but also troublesome transition from printed to electronic dictionaries, cf. Fuertes-Olivera and Bergenholtz (2011a), Granger and Paquot (2012). In this process the question has been raised whether we need a new theory that may guide the conception and production of lexicographical e-tools or if we can use the theories already developed in the era of printed works. In order to answer this question it is first of all necessary to give answer to another question, i.e. whether a lexicographical theory exists, is possible at all or even wanted. This is due to the fact that the very concept of theory is widely disputed within lexicographical circles; cf. Bergenholtz et al. (2008).

In a recent publication where he discusses the theory of lexicographical functions, Yukio Tono (2010: 2) asks: "Do we really need a 'theory'?" Tono's final answer to his own question is affirmative. At a high level of abstraction, i.e. independent of the specific theory in question, this view is shared by the Russian tradition (e.g. Scerba 1940, Sorokoletov 1978), the German lexicographical tradition (e.g. Duda et al. 1986, Wiegand 1989, Zöfgen 1994, Weber 1996), Danish lexicographers (e.g. Kromann et al. 1984, Bergenholtz and Tarp 2003), various South African lexicographers (e.g. Gouws 2011), the CzechAmerican lexicographer Zgusta (1992), and at least part of the Chinese tradition (e.g. Yong and Peng 2008), among many others. However, other lexicographers, especially some of those belonging to the Anglo-Saxon tradition, do not support this vision of lexicography. For instance, Atkins and Rundell (2008: 4) "do not believe that such a thing exists" (i.e. a theory of lexicography). And in a recent book, Henri Béjoint (2010: 381) writes:

I simply do not believe that there exists a theory of lexicography, and I very much doubt that there can be one. Those who have proposed a general theory have not been found convincing by the community, and for good reasons. A theory is a system of ideas put forward to explain phenomena that are not otherwise explainable. A science has a theory, a craft does not. All natural phenomena need a theory, but how can there be a theory of the production of artefacts? There are theories of language, there may be theories of lexicology, but there is no theory of lexicography. Lexicography is about all a craft, the craft of preparing dictionaries, as well as an art, as Landau (2001) says. It may be becoming more scientific, but it has not become a science. 
This point of view is strongly embedded in an Anglo-Saxon academic tradition according to which science is only related to natural phenomena and where all other phenomena are referred to the sphere of art and craft. As mentioned, this tradition is widely opposed by the traditions in other parts of the world. For instance, in Danish universities the students can study cultural science (kulturvidenskab), art science (kunstvidenskab), literature science (litteraturvidenskab), social science (samfundsvidenskab), information science (informationsvidenskab), among many other disciplines. More or less the same disciplines may be studied as sciences with academic degrees at German and South African universities.

Whether lexicography should or should not be considered a science is a question of dispute that basically has to do with the concept of science used by the particular scholar. As mentioned, Béjoint (2011) and the Anglo-Saxon academic tradition reject it. Wiegand (1998), who bases his views on a concept of science formulated by Posner (1988), considers lexicography to be a scientific research area but still not a science as it does not yet fulfil two of fifteen required criteria formulated according to this concept. By contrast, the Russian lexicographer V. Dorosevskij (quoted in Sorokoletov 1978: 79), who bases himself on another concept of science, defined lexicography as "the science of the classification processes of word material and its presentation in dictionaries". Although with another definition, this view is shared by Tarp (2008) who relates to the following concept of science taken from Philosophisches Wörterbuch (cf. Buhr and Klaus 1971: 1083, 1169):

\begin{abstract}
A science is a system of knowledge growing out of social practice and developing on an on-going basis, comprising the acknowledgement of the most important properties, causal connections and legal considerations of nature, society and philosophy; rooted in the form of concepts, categories, defined goals, laws, theories and hypotheses, and constituting the basis of Man's growing mastery of his natural and social environment. A science also consists of its own history, pre-theoretical ideas, contributions to methodology, directions for practical action etc.
\end{abstract}

If this concept of science is related to existing lexicographical theory and practice, it can be concluded that lexicography satisfies all the demands made on any branch of human activity that claims to be a separate science or area of academic study, cf. Tarp (2008: 6):

- It has its own object of study: dictionaries, or to be more precise the planning, production, design and usage of lexicographical works and the close relationship between these works and specific types of social need;

- it is rooted in the form of concepts, categories, theories and hypotheses;

- it comprises both the history of dictionaries and its own history, including pre-theoretical ideas;

- it contains independent contributions to methodology;

- it includes directions for practical action. 
As already mentioned, this vision of the academic status of lexicography basically depends on the underlying concept of science and in order to avoid unnecessary misunderstandings it should therefore be recommended that any future discussion of this status is always explicitly related to a specific concept of science and not just to science in general. In this respect, it is noteworthy that even a well-established discipline as information science which has the term science included in its very name comprises an internal tendency belonging to the Anglo-Saxon tradition which rejects or at least raises doubts over its status as a science, e.g. Machlup (1983), Brooks (1989) and Buckland (2012), a debate which other scholars regard as "not particularly rewarding", cf. Norton (2010: 8).

\section{Lexicographical theory}

It is impossible to read the academic literature on lexicography without coming up with the word theory. It is used as reference both to general theories that cover the whole subject field of lexicography as a discipline and to specific theories that cover any subarea of this enormous discipline. Some of the general theories are well-known: [Towards a] General Theory of Lexicography, cf. Scerba (1940), the General Theory of Lexicography, cf. Wiegand (1998), and the Function Theory, cf. Bergenholtz and Tarp $(2002,2003)$. In the above quoted article, Sorokoletov (1978: 79) writes:

In the Soviet period lexicography developed into an independent discipline with its own theory, own tasks and own methods for their solution.

In criticizing previous studies on the history of Chinese lexicography, among other things because "dictionary compilation is viewed as a purely linguistic activity", Yong and Peng (2008: 5) also stress the need for a theory to support this type of research:

It is frequently apparent in their research [the previous one] that more emphasis is laid on the parts than on the whole, that more attention is paid to the isolated analysis of cases than to theoretical generalizations, and that more consideration is given to accumulation of practical experiences than to formulation of lexicographical theories.

Even a scholar like Piotrowski (2009: 485) who is strongly critical of the function theory does not deny the need for a "new theory of lexicography". By analogue, Bogaards (2010) who has looked for the word theory in a corpus of texts from the International Journal of Lexicography also confirms that many scholars refer to theory in their reflections on dictionaries although he himself doubts that such a theory already exists.

Apart from these references to the existence of and need for more or less general theories, in the academic literature quite a lot of references to more specific lexicographical theories can also be found, e.g. a theory of bilingual lexicog- 
raphy (Duda et al. 1986), a theory of the lexicographical example (Hausmann 1985 and Zöfgen 1987), a theory of lexicographical language description (Wiegand 1983), a theory of the dictionary form (Wiegand and Morán 2009), etc. It is therefore simply wrong when it is claimed that no lexicographical theory exists although everybody is welcome to accept, critize or reject the existing theories but not to deny or ignore their existence. It goes without saying that the various lexicographical theories proposed are of a highly varying character as some of them are strongly embedded in linguistics whereas others are based upon the idea that lexicography is an independent discipline (and even science) with a strong interdisciplinary vocation. Besides, it must be admitted that reference to theory is frequently made without clarifying what is meant by theory. Just as was the case with the concept of science, there are also various "competing" concepts of theory to be found in the academic and philosophical literature. In this respect, the function theory is explicitly based upon the following concept of theory, once more taken from Philosophisches Wörterbuch (cf. Buhr and Klaus 1971: 155, 1083):

A theory is a systematically organised set of statements about an area of objective reality or consciousness, i.e. logical structures reflecting the fact that certain things have certain properties, or that certain relationships exist between these things.

In this veil, Tarp (2008: 9-11) defines a lexicographical theory in general as a systematically organised set of statements about dictionaries and other lexicographical works and their relationship with specific types of social need, and at the same time stresses that it is necessary to distinguish between different types of theory: general and specific theories, integrated and non-integrated theories (i.e. specific theories integrated or not in a general theory of lexicography), and contemplative and transformative theories.

It is noteworthy that Bogaards (2010: 316) — one of the few lexicographers who has published a specific criticism of the function theory - does not accept that this theory actually is a theory, most of all because it "lacks any form of empirically verifiable or falsifiable hypotheses". A similar comment was sent to the author of this article (Bogaards: Personal communication):

You finally define a theory (of lexicography) as 'a systematically structured set of statements'. Without going into long epistemological debates, I would say that a theory should first of all consist of a number of hypotheses and axioms, as well as of a set of methods to falsify the hypotheses.

Here it becomes clear that the discrepancy as to the validity of this specific theory is due to the underlying concept of theory used by each researcher. The function theory does not consider hypotheses to be part of the concept of theory, but as something pre-theoretical that may eventually lead to theory (or improved theory) and which belongs to the broader concept of science, cf. Buhr and Klaus (1971: 1169). Falsification is a highly useful method to validate theo- 
ries within many disciplines but, as Bergenholtz et al. (2008: 157-159) has argued, the idea that every theory has to be falsifiable is an idea taken over from natural sciences and the Popperian tradition which, as a rule, is not valid inside various social disciplines where a lot of empirically grounded theories have been formulated that are absolutely necessary in order to understand practice and make progress within these disciplines although they cannot be falsified in the same manner and with the same rigid criteria as theories related to natural sciences. The same can be said about lexicographical theories.

\section{A lexicographical theory is possible}

As mentioned above, Béjoint (2010: 381) bases himself upon the idea that "there is no theory of lexicography", "lexicography is about all a craft, the craft of preparing dictionaries, as well as an art" and that "a science has a theory, a craft does not". He then asks: "How can there be a theory of the production of artefacts?"

What should we think about these statements? First of all, it must be admitted that the practical production of dictionaries is neither a science nor a theory but a thousand-year-old cultural practice that can reasonably be defined or viewed as a craft which, as all other crafts, has developed historically with a view to satisfying certain needs detected in society. But this does in no way exclude that this craft - as well as the needs that give rise to it, its practical products (dictionaries and other lexicographical tools) and the use made of these - can be subjected to observation, empirical studies and theoretical generalizations. If one takes the point of departure in the above definition of the concept of theory it is perfectly possible:

(1) to observe and study this craft in all its dimensions,

(2) to isolate relevant phenomena with certain properties,

(3) to establish the relations existing between them,

(4) to make statements about these phenomena and relations, and

(5) to systematize these statements.

This is all it takes to formulate a coherent theory of lexicography if the underlying concept of theory is the one discussed above. It is also worth noting that this is actually what is done in the bulk of the academic literature on lexicography, at least in terms of the first four of the above steps, as it is still relatively rare to meet the necessary theoretical generalizations, cf. Yong and Peng (2008: 5), and the systematization of the statements made in the form of logical structures. The inevitable conclusion is therefore that a theory of lexicography is possible, and that various - frequently competing - general and specific theories of lexicography do exist.

It was such a theory capable of explaining, guiding and even renovating 
the existing practice that Scerba (1940) intended to formulate in his groundbreaking contribution to lexicography, this was what Wiegand did with his "general theory of lexicography", and what has been done with the "theory of lexicographical functions". It may be that these theories "have not been found convincing" by the Anglo-Saxon lexicographical community, but this does not mean that they do not exist, are not possible and even highly needed by those who try to solve the complex problems within present-day lexicography.

Whereas specific theories may deal with whichever area or subarea of the discipline, a general theory of lexicography should necessarily include all aspects of lexicography (including all types of dictionaries and other lexicographical works) and cannot be restricted only to a subset of dictionaries, e.g. dictionaries where special linguistic knowledge have been required. Oxford University Press, for instance, is not only the publisher of a range of advanced learners', school and concise dictionaries of English, bilingual as well as monolingual, but also of a whole series of dictionaries of archeology, classical civilization, military history, philosophy, law, economics, sociology, art, music, chemistry, biology, nursing, and so on. Other publishers have produced lexicographical works dealing with thousands of other topics, the confection of which requires highly specialized knowledge of these disciplines, but not of linguistics as a separate academic discipline.

A general theory of lexicography cannot ignore that lexicographical works are multi-faceted cultural artifacts and utility tools which, during the millenniums, have met a wide range of different needs detected in society and covered almost all spheres of human activity and knowledge, nor should it depart from the differences that separate all these works in terms of their specific content, structure etc., but from the aspects and elements that unite them and are common to all of them. These uniting aspects and elements can be considered the core of lexicography which, according to the function theory, is:

- the design of utility tools

- that can be quickly and easily consulted

- with a view to meeting punctual information needs

- occurring for specific types of users

- in specific types of extra-lexicographic situations.

If this core activity is studied and generalized in the form of a systematic set of statements, the theory formulated in this way will be able to guide the design not only of an entirely new generation of lexicographic works of the kind we already know, but also of consultation tools covering areas that have still not been treated lexicographically. No theory is born fully armed as Athena from Zeus' forehead and existing lexicographical theory, including the function theory, necessarily has to pass through a continuous process of validation and perfection as a result of the fruitful interaction with its alter ego, the lexicographical 
practice, which is also in a process of continuous progress. As the Danish lexicographer Henning Bergenholtz repeats time after time, cf. Nielsen and Tarp (2009: ix): "Nothing is more practical than a good theory".

Such a good theory of lexicography does not only exist today (although it should be continuously perfected), it is also highly needed in order to produce high-quality lexicographical tools in the on-going and troublesome transition from printed to electronic dictionaries.

\section{A new theory?}

The title of this contribution also raises the question whether we need a new theory of lexicography? The answer to this question is both yes and no, cf. Tarp (2011: 54). On the one hand it is evident that theories only dealing with printed dictionaries, e.g. the one developed by Wiegand and Morán (2009) regarding the dictionary form, cannot give answers to the challenges of electronic dictionaries. On the other hand, the use of the computer and information sciences as well as the increased focus on information in present-day society have made it clear that lexicography is above all an information discipline, a vision shared by a growing number of scholars, e.g. Bothma (2011), Fuertes-Olivera and Bergenholtz (2011b), Heid (2011), Leroyer (2011), among others. When an abstraction is made from the concrete and specific content of the needs that lexicographical works have intended to meet during its whole existence, what is left is their common character of information needs. Besides, if a distinction - as it was already done by Hausmann (1977: 144) — is made between global information needs, i.e. the needs related to a more profound study of a specific subject field (or part of it), and punctual information needs related to a single and limited topic within a larger subject field, or to the solution of specific tasks or problems, then it becomes clear that lexicographical works and tools are by excellence artefacts designed to be consulted in order to meet punctual information needs.

A short panoramic overview shows that lexicographical works are not the only types of artefacts produced with a view to satisfying punctual information needs. Manuals, how-to's, user guides, telephone books, and indexes in books are all text types totally or partially designed to be consulted in order to retrieve punctual information for one purpose or another. And the list can easily be extended, including even train, bus and flight plans, and other similar reference tools.

It is obvious that these tools have not been designed and produced according to lexicographical principles but it is nevertheless evident that they all have something fundamental in common with dictionaries and other lexicographical tools although they have developed from different traditions. One may in fact speak about the contours of one big discipline including all types of consultation tools designed to meet punctual information needs, a discipline which necessarily should develop its own general theory as part of information 
science. In the development of such a theory, lexicography has both a lot to contribute to other theories dealing with punctual consultation tools and to information science in general and a lot to learn from these theories and this science. In this respect, it is worth quoting the visionary words by Gouws (2011: 29):

Looking back at the development of the theory and practice of lexicography it is clear that for too long the practice of printed dictionaries had to go without a sound theory, for too long lexicography did not establish itself as an independent discipline, for too long the pool of lexicographers had been restricted to experts from a single field, for too long innovation in the lexicographic practice was impeded by its theory being a follower and not a leader, for too long lexicographic theory was exclusively directed at being implemented in the production of dictionaries. Looking at the future, the planning and compilation of electronic dictionaries and the further development of a coherent and medium-unspecific theory we need to unlearn a lot, we need to learn a lot so that we can be innovative and produce better reference tools, including even dictionaries.

The final conclusion is that lexicography will not cease to be an independent discipline with its own specific subject field as well as its own theory and practice but that it will tend to relate more and more to and interact with similar disciplines within the broad area of information science. Consequently, existing theory should not be rejected but should continuously be enhanced and improved through this hopefully fruitful interaction with sister disciplines. In this way, lexicographical theory will place itself in an even better position to assist and guide the present transition from printed to electronic dictionaries.

The gauntlet is down. Who will pick it up?

\section{Literature}

Atkins, B.T. Sue and Michael Rundell. 2008. The Oxford Guide to Practical Lexicography. Oxford: Oxford University Press.

Béjoint, Henri. 2010. The Lexicography of English. Oxford: Oxford University Press.

Bergenholtz, Carsten, Henning Bergenholtz and Sven Tarp. 2008. Leksikografi i videnskabsteoretisk perspektiv: sand, falsk eller irrelevant. LexicoNordica 15: 155-168.

Bergenholtz, Henning and Sven Tarp. 2002. Die moderne lexikographische Funktionslehre. Diskussionsbeitrag zu neuen und alten Paradigmen, die Wörterbücher als Gebrauchsgegenstände verstehen. Lexicographica 18: 253-263.

Bergenholtz, Henning and Sven Tarp. 2003. Two Opposing Theories: On H.E. Wiegand's Recent Discovery of Lexicographic Functions. Hermes, Journal of Linguistics 31:171-196.

Bogaards, Paul. 2010. Lexicography: Science without Theory? De Schryver, Gilles-Maurice (Ed.). 2010. A Way with Words: Recent Advances in Lexical Theory and Analysis. A Festschrift for Patrick Hanks: 313-322. Kampala: Menha Publishers.

Bothma, Theo J.D. 2011. Filtering and Adapting Data and Information in the Online Environment in Response to User Needs. Fuertes-Olivera, Pedro A. and Henning Bergenholtz (Eds.). 2011. 
e-Lexicography: The Internet, Digital Initiatives and Lexicography: 71-102. London/New York: Continuum.

Brooks, Terrence A. 1989. The Model of Science and Scientific Models in Librarianship. Library Trends 38(2): 237-249.

Buckland, Michael. 2012. What Kind of Science Can Information Science Be? Journal of the American Society for Information Science and Technology 63(1): 1-7.

Buhr, Manfred and Georg Klaus (Eds.). 1971. Philosophisches Wörterbuch. Band 1-2. Berlin: Das europäische Buch.

Duda, W., M. Frenzel, E. Wöller and T. Zimmermann. 1986. Zu einer Theorie der zweisprachigen Lexikographie. Überlegungen zu einen neuen russisch-deutschen Wörterbuch. Berlin: AkademieVerlag.

Fuertes-Olivera, Pedro A. and Henning Bergenholtz (Eds.). 2011a. e-Lexicography: The Internet, Digital Initiatives and Lexicography. London/New York: Continuum.

Fuertes-Olivera, Pedro A. and Henning Bergenholtz. 2011b. Introduction: The Construction of Internet Dictionaries. Fuertes-Olivera, Pedro A. and Henning Bergenholtz (Eds.). 2011. e-Lexicography: The Internet, Digital Initiatives and Lexicography: 1-16. London/New York: Continuum

Gouws, Rufus H. 2011. Learning, Unlearning and Innovation in the Planning of Electronic Dictionaries. Fuertes-Olivera, Pedro A. and Henning Bergenholtz (Eds.). 2011. e-Lexicography: The Internet, Digital Initiatives and Lexicography: 17-29. London/New York: Continuum.

Granger, Sylviane and Magali Paquot (Eds.). 2012. Electronic Lexicography. Oxford: Oxford University Press.

Hausmann, Franz Josef. 1977. Einführung in die Benutzung der neufranzösischen Wörterbücher. Tübingen: Max Niemeyer.

Hausmann, Franz Josef. 1985. Kollokationen im deutschen Wörterbuch. Ein Beitrag zur Theorie des lexikographischen Beispiels. Bergenholtz, Henning and Joachim Mugdan (Eds.). 1985. Lexikographie und Grammatik: Akten des Essener Kolloquiums zur Grammatik im Wörterbuch 2830.6.1984: 118-129. Lexicographica: Series Maior 3. Tübingen: MaxNiemeyer.

Heid, Ulrich. 2011. Electronic Dictionaries as Tools: Towards an Assessment of Usability. FuertesOlivera, Pedro A. and Henning Bergenholtz (Eds.). 2011. e-Lexicography: The Internet, Digital Initiatives and Lexicography: 287-304. London/New York: Continuum.

Kromann, Hans-Peder, Theis Riiber and Poul Rosbach. 1984. Überlegungen zu Grundfragen der zweisprachigen Lexikographie. Wiegand, Herbert Ernst (Ed.). 1984. Studien zur neuhochdeutschen Lexikographie V. Germanistische Linguistik 3-6: 159-238. Hildesheim/New York: Georg Olms.

Landau, Sidney. 2001. Dictionaries: The Art and Craft of Lexicography. Second Edition. New York/ Cambridge: Cam-bridge University Press.

Leroyer, Patrick. 2011. Change of Paradigm: From Linguistics to Information Science and from Dictionaries to Lexicographic Information Tools. Fuertes-Olivera, Pedro A. and Henning Bergenholtz (Eds.). 2011. e-Lexicography: The Internet, Digital Initiatives and Lexicography: 121140. London/New York: Continuum.

Machlup, F. 1983. Semantic Quirks in Studies of Information. Machlup, F. and U. Mansfield (Eds.). 1983. The Study of Information: Interdisciplinary Messages: 641-671. New York: John Wiley \& Sons. 
Nielsen, Sandro and Sven Tarp. 2009: Nothing is More Practical Than a Good Theory. Nielsen, Sandro and Sven Tarp (Eds.). 2009. Lexicography in the 21st Century. In honour of Henning Bergenholtz: ix-xi. Amsterdam/Philadelphia: John Benjamins.

Norton, Melanie J. 2010. Information and Information Science. Norton, Melanie J. (Ed.). 2010. Introductory Concepts in Information Science: 3-18. Second Edition. New Jersey: Information Today.

Piotrowski, Tadeusz. 2009. [Review of] Sven Tarp. Lexicography in the Borderland Between Knowledge and Non-knowledge. General Lexicographical Theory with Particular Focus on Learner's Lexicography. International Journal of Lexicography 22(4): 480-486.

Posner, Roland. 1988. What is an Academic Discipline? Claussen, Regina and Roland DaubeSchackat (Eds.). 1988. Gedankenzeichen. Festschrift für Klaus Oehler zum 60. Geburtstag: 165-185. Tübingen: Stauffenburg Verlag.

Scerba, L.V. 1940. Towards a General Theory of Lexicography. International Journal of Lexicography 8(4), 1995: 315-350.

Sorokoletov, F.P. 1978. Traditionen der sowjetrussischen Lexikographie. Wolski, Werner (Ed.). 1982. Aspekte der sowjetrussischen Lexikcographie. Übersetzungen, Abstracts, bibliographische Angaben: 63-88. Tübingen: Max Niemeyer.

Tarp, Sven. 2008. Lexicography in the Borderland between Knowledge and Non-knowledge. General Lexicographical Theory with Particular Focus on Learner's Lexicography. Lexicographica. Series Maior 134. Tübingen: Max Niemeyer.

Tarp, Sven. 2011. Lexicographical and Other e-Tools for Consultation Purposes: Towards the Individualization of Needs Satisfaction. Fuertes-Olivera, Pedro A. and Henning Bergenholtz (Eds.). 2011. e-Lexicography: The Internet, Digital Initiatives and Lexicography: 54-70. London/ New York: Continuum.

Tono, Yukio. 2010. A Critical Review of the Theory of Lexicographical Functions. Lexicon 40: 1-16.

Weber, Nico. (Ed.). 1996. Theorie der Semantik und Theorie der Lexikographie. Tübingen: Max Niemeyer.

Wiegand, Herbert Ernst. 1983. Was ist eigentlich ein Lemma? Ein Beitrag zur Theorie der lexikographischen Sprachbeschreibung. Wiegand, Herbert Ernst (Ed.). 1983. Studien zur neuhochdeutschen Lexicographie III: 401-474. Germanistische Linguistik 1-4/1982. Hildesheim/New York: Georg Olms Verlag.

Wiegand, Herbert Ernst. 1989. Der gegenwärtige Status des Lexikographie und ihr Verhältnis zu anderen Disziplinen. Hausmann, Franz Josef, Oskar Reichmann, Herbert Ernst Wiegand and Ladislav Zgusta (Eds.). 1989-1991. Wörterbücher. Ein internationales Handbuch zur Lexikographie: 246-280. Berlin/New York: Walter de Gruyter.

Wiegand, Herbert Ernst. 1998. Wörterbuchforschung. Untersuchungen zur Wörterbuchbenutzung, zur Theorie, Geschichte, Kritik und Automatisierung der Lexikographie. 1. Teilband. Mit 159 Abbildungen im Text. Berlin/New York: Walter de Gruyter.

Wiegand, Herbert Ernst and María Teresa Fuentes Morán. 2009. Estructuras lexicográficas. Aspectos centrales de una teoría de la forma del diccionarío. Granada: Edicíones Tragacanto.

Yong, Heming and Jing Peng. 2008. Chinese Lexicography. A History from 1046 BC to AD 1911. Oxford: Oxford University Press.

Zgusta, Ladislav. 1992. The Czech-Chinese Dictionary and the Theory of Lexicography. International Journal of Lexicography 5(2): 85-128. 
Zöfgen, Ekkehard. 1987. Kollokation - Kontextualisierung - (Beleg-)Satz. Anmerkungen zur Theorie und Praxis des lexikographischen Beispiels. Barrera-Vidal, Alberto, Hartmut Kleineidam, Manfred Raupach (Eds.). 1987. Französische Sprachlehre und bon usage. Festschrift für Hans Wilhelm Klein zum 75. Geburststag: 219-238. München: Max Hueber.

Zöfgen, Ekkehard. 1994. Lernerwörterbuch in Theorie und Praxis. Ein Beitrag zur Metalexikographie mit besonderer Berücksichtung des Französischen. Lexicographica. Series Maior 59. Tübingen: Max Niemeyer. 